\title{
A voice with no words
}

\author{
The first blog from a biotech company goes live.
}

Corpo orporate biotech finally entered the Web 2.0 world last month, with the launch of a blog (http://www.cnto411.com) by Centocor, the biologics division of Johnson \& Johnson. There are plenty of other pharma and biotech-related blogs outs there, stream-of-consciousness outpourings of various quality from people who see themselves as commentators on the industry and its activities. Some of the most insightful, topical and entertaining are from industry insider Derek Lowe (http://pipeline.corante.com), veteran journalist Ed Silverman (http://www.pharmalot.com) and the editors of Windhover's In Vivo (http://invivoblog.blogspot.com/). What distinguishes the Centocor blog is that it is the first that comes from within a biotech company with the company imprimatur.

It is penned, or keyboarded, by the Senior Director of Corporate Communication at Centocor, Melissa Katz. In her explanation of the purpose and scope of the blog, Katz says that she will not comment on many of the issues that surround the company and its products "because [the] industry is highly regulated." Consequently, there will be nothing on Centocor product-specific news or issues, nor anything that might compromise approval of products, nor competitor products or issues.

One problem with this is that although obviously it's very early in the development of the blog's content, the restrictions don't seem to leave Katz much room for maneuver. She tells us about launching the blog (March 1), guidelines for the blog (March 4), the departure of Centocor president Neil Fowler (March 5), communication of diagnoses to patients by physicians (March 10), the response from Centocor employees to the blog (March 11), the history of Centocor and the derivation of the company's name.

It is tempting to echo Dorothy Parker in suggesting that, taken together, the topic list "runs the entire gamut of content from B to C"-specifically from blog to Centocor corporate communication. But the question is whether, with company legal eagles presumably neutering content and gagging the author's remit, the blog can rise above the trivia and chart new territory. Because a blog like this could actually transform the way in which many people view biotech businesses as well as how biotech businesses communicate with people.

In the traditional execution of corporate communications, companies become pretty much synonymous with the actions of their products. If their marketing people have been effective, companies also can be aligned with the values that are attached to those brands. But firms clearly want to project a more human and holistic image of themselves. In their annual reports, for instance, companies personalize their activities, not only publishing the comments and actions of the CEO and management team, but also drawing pen portraits of staff in more lowly but essential positions: cleaners, maintenance staff, bench researchers, even business developers.

Community engagement with a company can be a powerful force. Plans to ban recombinant DNA experiments in Switzerland were abandoned following a referendum vote: the decisive factor in this was not just the sheer economic power of the Swiss pharma industry but the power of employee numbers-between them, the mega- pharma companies and their dependent suppliers employed hundreds of thousands of people, each of them with ten neighbors and ten friends and ten family members. That's an awful lot of enlightened self-interest. Similarly, deCODE Genetics was able to influence opinion in Iceland: although the firm employs only a few hundred people, the small size of the Icelandic population $(250,000)$ and its genetic interconnectedness meant that virtually everybody in the country had first- or second-hand knowledge of the company.

Blogs from companies about companies could take that process beyond local communities, projecting their business not just as outperforming ticker symbols or geek-driven black-box houses of abstruse experimentation but as collection of interacting real, human people. The power of a blog doesn't lie in its rousing rhetoric but in engaging the outside people with the inside people, in providing the first draft not of history, but of a soap-opera script. A blog can get past the idea that the entire company is personified by the words of its spokespeople or the charisma of the CEO. A blog can give companies color and multiple, untutored voices.

One can also imagine an instance-perhaps an industry scandal or media debate that reflects indirectly on Centocor and other biotech companies in a negative manner-in which the blog would be a rapid way of engaging with stakeholders and communicating the industry viewpoint, which is so often drowned out by those with extreme viewpoints, who pitch for headlines and make good copy.

The blog, then, would be one more means of informally participating in debates about important industry issues and would be used to rapidly correct misinformation. The important aspect for Centocor and other biotech companies to appreciate is that the information exchange is two-way. Blogs are not only a means of pushing out information and opinions to the public domain. They are also a means of exploring issues, product ideas and marketing strategies and of gathering information and opinions that can then be steered back into internal corporate decision-making. And although those who comment on blogs are a particular demographic of the public at large, they are still a useful bellwether for opinions and views that may be circulating outside of the industry.

All this is a very long way from what is currently taking place on the Centocor blog, which seems more of an afterthought than a key strategic communications tool. Melissa Katz is not yet a spontaneous voice. And her voice is pretty much the only voice (with brief responses from a few other Centocor employees). To go beyond a relaxed and fairly boring form of Centocor spokesmanship, the company should consider broadening the blog's remit. Loosen control without losing it entirely.

At the moment, Centocor's blog isn't contributing much beyond an unexpurgated stream of consciousness. That will simply not be enough to register above the static of the internet. So the question is, What's the point? To exploit the power of Web 2.0 and the feedback of those who read and comment on blogs, a blog needs to establish an audience. To have an audience, it needs to find a voice. And in order to have a voice, it needs to start saying something. 